\title{
Physicochemical and Microbiological Assessment of Drinking Water in Kari Estate Bauchi Nigeria
}

\author{
Muhammad M Abubakar (Corresponding Author) \\ Department of Animal Production, Faculty of Agriculture and Agricultural Technology, Abubakar Tafawa Balewa \\ University, Bauchi, Nigeria \\ Email: mmjambure@yahoo.com
}

\section{Ibrahim Khalil Abubakar}

Integrated Science Education, Federal College of Education (Technical), Bichi, Kano State, Nigeria

\author{
Article History \\ Received: February 25, 2020 \\ Revised: March 20, 2020 \\ Accepted: March 26, 2020 \\ Published: March 28, 2020 \\ Copyright (c) 2020 ARPG \& \\ Author \\ This work is licensed under \\ the Creative Commons \\ Attribution International \\ (9) (1) CC BY: Creative \\ Commons Attribution \\ License 4.0
}

\begin{abstract}
Some sources of drinking water in Kari Estate in Bauchi Metropolis were analyzed for physicochemical contents and coliform contamination. A total of five samples were collected from different sources as follows: 2 sachets water, 2 wells, and tap water. The physicochemical analysis included the determinations of temperature, $\mathrm{pH}$, electrical conductivity, total dissolved solids, turbidity, colour, suspended solids, odour, taste, total hardness, iron, nitrate, nitirite, manganese, ammonia, fluoride and cyanide. The two wells had total coliforms of 6 and 10 and faecal coliforms of 4 and 5 respectively. Tap water had total and faecal coliforms of 7 and 3 respectively. E. coli were identified in the samples from wells while Bacillus sp. were found in the tap water. Although the physicochemical contents of the samples were normal range, coliform counts of the wells and tap water were above those set by the Nigerian Industrial Standards (NIS) and the World Health Organization (WHO) standards. Presence coliforms above the standards indicates contamination and that the water may be unsafe for drinking. The presence of E. coli suggests that improvement in monitoring and water hygiene practices should be employed to improve the drinking water quality.
\end{abstract}

Keywords: Total coliforms; Faecal coliform; E. coli; Membrane filtration; Physicochemical analysis; Contamination.

\section{Introduction}

A substantial number of Nigeria's 201 million people [1] use tap water, wells, and packaged sachet water as the easily assessed and cheap commercial source of drinking water. Conformation of these sources of water with set regulatory standards is of special interest because of their capacity to spread diseases within a large population. Nearly $90 \%$ of diarrhea related cases and deaths have been attributed to unsafe or inadequate water supplies and sanitation conditions [2]. As of $15^{\text {th }}$ April, 2020, the number of deaths in the world in 2020 attributed to water related diseases (more than 240,000) is much more than the number of deaths (less than 130,000) caused by the dreaded coronavirus [3]. Safe drinking water, which is essential for the survival of humans and animals, is unavailable to over one billion of the world's people living in poverty [4]. The World Health Organization have highlighted at least seventeen different genera of bacteria that may be found in drinking water sources which can cause disease in man WHO [5] and animals World Health Organization [6].

Water resources have been the most exploited natural system since the world began, and it is used for domestic, industrial and agricultural activities [7]. Water security is a worldwide pressing social justice and human rights issue. Water, which is one of the most important and most abundant compounds on earth, is vital to the survival of any organism, including humans and animals [8]. Water is an essential nutrient which is involved in all basic physiological functions of the body. Relative to other nutrients, water is consumed in considerably larger quantities. Therefore, its availability and quality are extremely important for animal health and productivity [9].

To maintain a physiological balance of water, most animals must drink every few days to survive, and at least every other day to be productive. However, regarding highly producing animals, provision of a large amount of clean, fresh water is essential [9]. Water is a nutrient of extreme importance for animals and intimately involved in a wide array of bodily functions. It serves as the universal solvent in the extracellular and intracellular compartments, as $99 \%$ of all molecules in the body are carried in it NRC National Research Council [10].

The current study was aimed at determining the purity and safety of some drinking water sources for man and animals by assessing their coliform bacterial load. The study specifically aimed to ascertain the quality of drinking water in Kari Housing Estate, a suburb of Bauchi Metropolis, through physicochemical and microbiological analysis of the different water sources in the study area. 


\section{Materials and Methods}

\subsection{Study Area}

The study area was Kari Housing Estate of the Abubakar Tafawa Balewa University, located along Maiduguri Road, Bauchi, Nigeria (latitude $10^{\circ} 18^{\prime} \mathrm{N}$ and longitude $9^{0} 50^{\prime} \mathrm{E}$ ).

\subsection{Water Samples}

Drinking water samples ( 3 replicates each) from 2 different wells, 2 different sachets water and a tap were analyzed. Water samples from the tap and wells were collected using sterile bottles of at least $200 \mathrm{ml}$ capacity. During this collection, all bottles were held at the base in order to avoid contact with hands. It was also ensured that the mouth of the tap was flamed, and the water was allowed to run for about 90 seconds before being allowed to fall into the sample bottles. All samples were labeled with the details of collection and were transported to the laboratory of Bauchi Water Treatment Plant, Bauchi State, Nigeria in an insulated cool bar for analysis.

The physicochemical and microbiological parameters of each sample were determined immediately on collection. The physicochemical parameters of the water samples were determined using known standard methods [11].

\subsection{Tests for $\mathrm{pH}$ and Temperature}

The $\mathrm{pH}$ meter was warmed for 15 minutes, rinsed with fresh distilled water and wiped dry. The meter was standardized using the buffer solutions at the temperature $25^{\circ} \mathrm{C}$ with the $\mathrm{pH}$ knob switched on. It was then switched off, removed from the buffer, rinsed and wiped. The meter was inserted into the sample, the $\mathrm{pH}$ knob was then switched on and the readings for temperature and $\mathrm{pH}$ on the scales taken.

\subsection{Test for Colour}

This procedure was carried out using Lovibond colour disc. The tube was filled to the mark with distilled water and placed in the left sample position 1 on the comparator. The other tube was filled, also to the mark, and placed in the right sample position. The colour disc was then placed and rotated to match the colour, and the number on the disc recorded.

\subsection{Test for Odour}

Known volumes of the sample were pipetted into each of several 500ml conical flasks. Each of them was diluted to $200 \mathrm{ml}$ with odour-free water, then shaken and stoppered. These dilutions and the reference odour-free water were heated to $40{ }^{\circ} \mathrm{C}$. The flasks were shaken (reference first), opened and the vapour was sniffed. Sniffing of vapour was repeated on the samples, starting from the lowest dilution and observations were recorded.

\subsection{Test for Taste}

Small volumes of each sample were tasted with the tongue and then immediately rinsed with taste free distilled water after each sample, and the result recorded accordingly.

\subsection{Test for Total Hardness}

$100 \mathrm{ml}$ of water sample was pipetted into each of three $250 \mathrm{ml}$ conical flask. $1 \mathrm{ml}$ of buffer solution was added, swirled and 3 drops of indicator were added. It was then titrated against $0.02 \mathrm{~N}$ EDTA solution until change of odour occurred. The EDTA solution was standardized against the standard calcium solution using $10 \mathrm{ml}$ portion to check the EDTA titre and the $10 \mathrm{ml}$ to $50 \mathrm{ml}$ was diluted in water.

Tests for E-Conductivity and Total Dissolved solids (TDS) and Suspended Solids were carried out using the Conductivity/TDS Digital Meter. Turbidity was measured using Potalab Turbidity Meter and were all done according to the manufacturer's specification [12].

The determinations for Ammonia, Nitrate, Nitrite, Flouride, Manganese, Cyanide and Iron were done using the Potalab Photometer, and were performed according to the manufacturer's specification [12].

The Membrane filtration technique, according to Wagtech [12] was used in determining the number of coliforms. The media used was Membrane Lauryl Sulphate Broth (MLSB) and was prepared according to the manufacturers' specification [12].

\subsection{Membrane Filtration}

Membrane filtration method described by Wagtech [12] was followed, whereby $100 \mathrm{ml}$. of each water sample was filtered through sterile membrane which retained the bacteria on its surface. The membrane was removed aseptically and placed on a MLSB medium in a petri-dish, the filtration was done for a second time, and was placed onto another MLSB media. All the petri-dishes were labeled with sample number, place, date and time. This procedure was repeated for all the remaining samples, and were placed into the incubator which provide places for inserting the two racks. $44^{\circ} \mathrm{C}$ was set on the first rack for faecal coliform incubation, and $37^{\circ} \mathrm{C}$ on the second rack for total coliform. The period of incubation for all the samples was 17 hours. Colonies were counted and recorded as colony forming unit (CFU) on fresh sheets. 


\subsection{Gram Staining}

The glass slide containing the smear was placed on the staining rack and covered with crystal violet stain and allowed for $60 \mathrm{sec}$. The stain was then washed off with distilled water. The water was then completely tipped off and the smear was covered with Lugol's iodine for $60 \mathrm{sec}$. The iodine was also washed off using distilled water. The smear was then decolorized rapidly with acetone and washed immediately with clean water. The smear was covered with neutral red stain for $2 \mathrm{~min}$, and washed off using clean water. The back of the slide was wiped clean, and placed on a draining rack for the smear to air-dry. Using a microscope, the smear was examined with 40x objective lens, to check the staining and to see the distribution of the material [13].

\subsection{Identification}

E. coli was identified by streaking method. Inoculum loop from positive EC Broth tube on Eosin Methylene Blue Agar plates was streaked and incubated for $24 \mathrm{hrs}$ at $35^{\circ} \mathrm{C}$. E. coli colonies were confirmed by indole test.

\subsection{Indole Test}

The isolates were grown in $5 \mathrm{ml}$ of nutrient broth at $37^{\circ} \mathrm{C}$, after the incubation, 3 drops of Kovac's indole reagent were added and shaken gently [13].

\section{Results}

The physicochemical analysis and microbial identification of samples in well water, tap water and commercial sachet water are summarized in Table 1.

Table-1. Physicochemical Analysis and Microbial identification in Well Water (A, B), Tap (T) and Sachets (S1, S2)

\begin{tabular}{l|l|l|l|l|l|l}
\hline & PARAMETERS & Sample A & Sample B & Sample T & Sample S1 & Sample S2 \\
\hline 1 & Temperature $\left({ }^{\circ} \mathrm{C}\right)$ & 27.0 & 27.1 & 27.1 & 27.3 & 27.3 \\
\hline 2 & pH & 6.51 & 6.40 & 6.67 & 6.49 & 6.61 \\
\hline 3 & $\begin{array}{l}\text { E-conductivity } \\
(\mu \text { s/cm) }\end{array}$ & 901.33 & 1006 & 672.67 & 79.56 & 113.46 \\
\hline 4 & T.D.S (mg/L) & 451 & 502.7 & 336 & 39.8 & 56.7 \\
\hline 5 & Turbidity (mg/L) & 12.17 & 0.25 & 0.80 & 0.19 & 0.52 \\
\hline 6 & Colour (mg/L) Pt & 91 & 9.67 & 0 & 0 & 0.03 \\
\hline 7 & S. solids (mg/L) & 6.67 & 3.67 & 2 & 0 & 1 \\
\hline 8 & Odour & $\begin{array}{l}\text { Unobjectio } \\
\text { nable }\end{array}$ & $\begin{array}{l}\text { Unobjectio } \\
\text { nable }\end{array}$ & $\begin{array}{l}\text { Unobjectio } \\
\text { nable }\end{array}$ & $\begin{array}{l}\text { Unobjectio } \\
\text { nable }\end{array}$ & $\begin{array}{l}\text { Unobjectio } \\
\text { nable }\end{array}$ \\
\hline 9 & Taste & $\begin{array}{l}\text { Unobjectio } \\
\text { nable }\end{array}$ & A bit Salty & $\begin{array}{l}\text { Unobjectio } \\
\text { nable }\end{array}$ & $\begin{array}{l}\text { Unobjectio } \\
\text { nable }\end{array}$ & $\begin{array}{l}\text { Unobjectio } \\
\text { nable }\end{array}$ \\
\hline 10 & $\begin{array}{l}\text { Total Hardness } \\
(\text { as CaCO3) mg/L }\end{array}$ & 194.3 & 215.3 & 133 & 10.3 & 20.7 \\
\hline 11 & Iron $(\mathrm{mg} / \mathrm{L})$ & 2.09 & 0.55 & 0.03 & 0.06 & 0.04 \\
\hline 12 & Nitrate (mg/L) & 44.08 & 94.33 & 39.33 & 18.47 & 17.12 \\
\hline 13 & Nitrite (mg/L) & 0.047 & 0.015 & 0.013 & 0.067 & 0.036 \\
\hline 14 & $\begin{array}{l}\text { Manganese } \\
(\mathrm{mg} / \mathrm{L})\end{array}$ & 7.3 & 0.2 & 2.6 & 0.1 & 0.1 \\
\hline 15 & Ammonia (mg/L) & 0.11 & 0.837 & 0.003 & 0 & 0.007 \\
\hline 16 & Fluoride (mg/L) & 0.84 & 2.03 & 1.14 & 0.003 & 0.007 \\
\hline 17 & Cyanide (mg/L) & 0.007 & 0 & 0.003 & 0 & 0.003 \\
\hline 18 & $\begin{array}{l}\text { Total Coliform } \\
(\text { cfu/100ml) }\end{array}$ & 6 & 10 & 7 & 0 & 0 \\
\hline 19 & $\begin{array}{l}\text { Faecal Coliform } \\
(\text { cfu/100ml) }\end{array}$ & 4 & 5 & 3 & 0 & 0 \\
\hline 20 & E. coli & Positive & Positive & Negative & Negative & Negative \\
\hline & & & & & \\
\hline
\end{tabular}

\section{Discussion}

The study revealed that samples from sachets water contained no coliforms, and hence safe for consumption. However, all the samples from wells and tap contained some amount of total and faecal coliforms, which indicates contamination. E. coli was detected in the samples from the two wells while Bacillus was detected in the tap water. Samples A, B and T had total coliforms of 6,10 and 7 respectively, which did not exceed the limits set by the WHO. However, faecal coliforms were present in all of the samples (4, 5 and 3 respectively for Samples A, B and T). These numbers exceeded the limits set by the WHO. According to NIS [14], drinking water should have 0 faecal coliform counts. Samples from the sachets water, S1 and S2 had no total and faecal coliform counts, hence are safe for consumption.

E. coli were positive in samples A and B. Presence of E. coli in drinking water indicates that the water has been contaminated with human or animal faeces and can lead to gastroenteritis with symptoms like diarrhea [15]. Presence of faecal coliform and E. coli may be due to contamination in water by faecal matter due to open defecation 
or due to the percolation of contaminated water into these resources [16]. No E. coli were detected in all the sachets water samples, which indicated that all the sachet water samples were free from any faecal contamination. Similar studies were carried out by Franciska, et al. [17] who analyzed the quality of drinking water from private water supplies in Netherlands. Their results show that $10.9 \%$ samples were contaminated due to E. coli and Enterococci presence. Similarly, studies were conducted by Hamida, et al. [18] for bacteriological analysis of drinking water of hand pumps in various schools of Peshawar city. They reported that only $8 \%$ samples were found free from bacterial contamination while remaining $92 \%$ samples were positive for bacterial contamination and unfit for drinking. Zahoorullah [19], carried out studies for drinking water quality in rural Peshawar. Water samples were collected from wells and storage tanks. Their results showed that only $13 \%$ samples were negative for bacterial contamination, $40 \%$ were found in the satisfactory level and $47 \%$ samples were found to be highly contaminated.

The current study shows that samples A had temperature mean of $27.0^{\circ} \mathrm{C}, \mathrm{B}$ and $\mathrm{T}$ had temperature mean of $27.1^{\circ} \mathrm{C}$, while samples $\mathrm{S} 1$ and $\mathrm{S} 2$ had mean temperature of $27.3^{\circ} \mathrm{C}$, hence complying with the maximum permitted level of $40^{\circ} \mathrm{C}$ set by the World Health Organization [20].

The $\mathrm{pH}$ values of samples A, T and $\mathrm{S} 2$ had mean of 6.51, 6.67, 6.61 respectively, and therefore in agreement with the standard $\mathrm{pH}$ for drinking water which ranges from $6.5-8.5$ [20, 21]. Samples B and $\mathrm{S} 1$ had lower $\mathrm{pH}$ values of 6.40 and 6.49 respectively. A study carried out in Abia State, Nigeria by Sunday and Innocent [22] had a similar result with most of the samples having $\mathrm{pH}$ range within the standards. Mustafa, et al. [23], who worked on the physicochemical and bacteriological analyses of drinking water in Maiduguri, Nigeria, found some samples below the range set by the WHO. Satihal, et al. [24], studied the quantitative and qualitative bacterial analysis of underground water of Vijayapur, India and found similar results, with $\mathrm{pH}$ of some samples below the range set by WHO. Even though $\mathrm{pH}$ has no direct effect on human health, its indirect action on physiological process cannot be over emphasized [25, 26].

Turbidity of samples B, T, S1 and S2 had mean value of $0.26,0.80,0.19$ and 0.52 respectively, hence, not exceeding the maximum permitted level set by the WHO and NIS [14]. Sample A had higher turbidity of mean 12.17. Similar studies were conducted by Shittu, et al. [27], who collectedma total of 4 sample: 2 from well, one from stream and one from river. Results showed that turbidity samples of the well water samples were within the permissible limits of WHO, while some samples had high turbidity of above limits. The high turbidity observed in sample A did not agree with EPA standards on turbidity. High turbidity is often associated with higher levels of disease-causing microorganisms such as bacteria and other parasites. Fewer number of disease-causing microorganisms may be an indication of lower turbidity value experienced with well samples. According to EPA (2002), at no time should turbidity (cloudiness of water) go above 5 nephelometric units (NTU).

The electronic-conductivity of samples A, T, S1 and S2 did not exceed the limit of $1000 \mu \mathrm{s} / \mathrm{cm}$. However, sample B had a mean value of $1006 \mu \mathrm{s} / \mathrm{cm}$, which is just above the limit set by NIS (2007). E-conductivity has close relationship with total dissolved solids. Thus, high E-conductivity value indicate that there are high concentration of dissolved solids in water [28].

Total dissolved solids (TSD) of sample B was approximately 503, barely exceeding the standard recommended by WHO, NAFDAC and NIS (500 mg/L). This result is similar to the physicochemical and bacteriological analyses of drinking water carried out in Maiduguri, Nigeria, by Mustafa, et al. [23], where one of the samples exceeded the standard recommended by the WHO. TDS of all the other water samples were in agreement with the Environmental Protection Agency standard and Nigerian Industrial Standards of 500mg/L [14, 29]. A study on the physicochemical and bacteriological analyses of water used for drinking and swimming purposes in Abeokuta, Nigeria, by Shittu, et al. [27] showed similar result of TDS not exceeding the standards. Total dissolved solid in drinking water has been associated with natural sources, sewage urban runoff, industrial waste water and chemical used in the water treatment process [29], though of aesthetic rather than health hazards [30].

Suspended solids of Sample A had mean value of $6.67 \mathrm{mg} / \mathrm{L}$; Sample B, $3.67 \mathrm{mg} / \mathrm{L}$; Sample T, $2 \mathrm{mg} / \mathrm{L}$; Sample $\mathrm{S} 1,0 \mathrm{mg} / \mathrm{L}$ and Sample S2, $1 \mathrm{mg} / \mathrm{L}$. WHO recommended TSS concentration value as $5 \mathrm{mg} / \mathrm{L}$. Hence sample A was found to be above the permissible limits of WHO, while remaining samples were within the permissible limits. Total suspended solids most important water pollutants and play major role in the transmission of pathogens, because total suspended solids smaller in size and greater the surface area per unit mass of particles thus provide a medium for pathogens attachment and carry pollutant load on the surface of particles. Number of disease causing microbes and parasites are correlated to high level of turbidity and total suspended solids [31].

The Total Hardness of these water samples shows that Samples T, S1 and S2 were within the permissible limits, and hence soft water. Samples A and B $194.3 \mathrm{mg} / \mathrm{L}$ and $215.3 \mathrm{mg} / \mathrm{L}$ respectively, hence exceeding the permissible limits. According to NIS [14], the maximum permitted limits for total hardness is $150 \mathrm{mg} / \mathrm{L}$. For aesthetic reasons, a limit of $500 \mathrm{mg} / \mathrm{L}$ is typically recommended for potable water supplies [2].

The colour of Samples A, T, S1 and S2 were within the limits recommended by NIS [14]. Sample B had colour of mean $91 \mathrm{mg} / \mathrm{L}$, which is very high and exceeded the maximum permitted level.

All samples, except sample B were found to be unobjectionable on their tastes. These samples were within the permitted levels recommended by NIS [14]. However, sample B had a bit salty taste. Roohul-Amin, et al. [28] reported that water with high EC value has salty taste. The water samples analysed in this study all had unobjectionable odour which is in agreement with standard of odour of limit of drinking water which is 3 threshold odour number [29]. The value of Manganese in Samples B, S1 and S2 did not exceed the permissible limits of 0.2 $\mathrm{mg} / \mathrm{L}$ [14]. However, Samples A and T had mean values of 7.3 and 2.6 respectively.

The levels of nitrate in all samples except sample B were generally within the permissible limit. Sample B had a mean value of $94.33 \mathrm{mg} / \mathrm{L}$, which is above the NIS and WHO recommended levels. The WHO and NIS standard for 
nitrate is $50 \mathrm{mg} / \mathrm{L}$ and above this limit may cause cyanosis disease or blue baby syndrome in infants less than 3 months [2]. The levels of Nitrite in all the samples were within the permissible limits of $0.2 \mathrm{mg} / \mathrm{L} \mathrm{recommended} \mathrm{by}$ WHO and NIS. The iron content of samples T, S1 and S2 were in agreement with EPA NIS standard of $0.3 \mathrm{mg} / \mathrm{L}$ [14, 29]. However, Samples A and B had mean values of 2.09 and $0.55 \mathrm{mg} / \mathrm{L}$ respectively, hence exceeding the maximum permitted levels recommended by NIS [14]. The levels of fluoride in all samples except sample B were generally within the permissible limit. Sample B had a mean value of $2.03 \mathrm{mg} / \mathrm{L}$, which is above the NIS and WHO recommended levels of $1.5 \mathrm{mg} / \mathrm{L}$. Fluoride content of all water samples fell within the standard limit of NSDWQ $(1.5 \mathrm{mg} / \mathrm{l})$, likewise the copper content of all the water samples used in this study which is in agreement with NSDWQ standard of $1 \mathrm{mg} / \mathrm{l}$. Although, presence of copper above the standard set by NSDWQ may cause gastrointestinal distress with a shorter-term exposure, while a long-term exposure may experience liver or kidney damage [21]. The Cyanide content of all the samples did not exceed the permissible level of 0.01, as recommended by the NIS [14].

\section{Conclusion}

The current study reveals that the wells and tap water analyzed had coliforms above the standard, hence not safe for consumption. Samples from sachets water had no coliform counts and considered safe for consumption, as recommended by WHO. The study had shown that some of the physiochemical and bacteriological parameters of drinking water were found above the permissible limits of WHO. In order to meet the potability of well water, it is recommended that continuous, effective treatment combined with constant monitoring is essential to ensure that it meets the standards of drinking water.

Proper well location and control of human activities to prevent sewage from entering water body is the key to avoiding bacterial contamination of drinking water. It is evident that water borne diseases are due to improper disposal of refuse contamination of water by sewage surface run off, therefore programmes should be organized to educate the general populace on the proper disposal, treatment of sewage and the need to purify our water to make it fit for drinking and educative programmes must be organized by researchers and government agencies to enlighten the people.

\section{References}

[1] PRB, 2019. "World population data sheet." In Population Reference Bureau. 1875 Connecticut Avenue, NW, Washington, DC.

[2] World Health Organization, 2006. Guidelines for drinking water quality. 3rd ed. vol. 33. Switzerland: WHO Press. pp. 71-115.

[3] Anon, 2020. "Coronavirus update-worldometer." Available: www.worldometers.info

[4] World Bank, 2009. World development report 2010: Development and climate change. Washington D.C.

[5] WHO, 2004. Guidelines for drinking water quality. Geneva, Switzerland: World Health Organization Press.

[6] World Health Organization, 2001. Guidelines for drinking water quality. Recommendation, Geneva, p. 130.

[7] Agwu, A., Avoaja, A. G., and Kalu, A., 2013. "The assessment of drinking water sources in aba metropolis, Abia State, Nigeria." Resources and Environment, vol. 3, pp. 72-76.

[8] Tortora, G. J., Funke, B. R., and Case, C. L., 2018. Microbiology: An Introduction. 11th ed. Boston, MA: Pearson Pub., p. 960.

[9] CCME Canadian Council of Ministers of the Environment, 2005. "Canadian water quality guidelines for the protection of agricultural water uses: Summary table." In Canadian Environmental Quality Guidelines, Canadian Council of Ministers of the Environment, Winnipeg.

[10] NRC National Research Council, 2007. Nutrient requirements of small ruminants. Washington, DC.: Natl. Acad. Press.

[11] NWRI, 1997. Outreach department. Nigeria: National Water Resources Institute - Kaduna.

[12] Wagtech, 2011. The definitive guide to portable water testing. Wagtech water technology (wtd). UK: Palintes Ltd., Gateshead, Tyne and Wear.

[13] Prescott, L. M., Harley, J. P., and Klein, D. A., 2002. Microbiology. 5th ed. New York, NY: McGraw-Hill, Companies.

[14] NIS, 2007. Nigerian standard for drinking water quality. Nigerian industrial standard. Lekki, Lagos, Nigeria: SON Press.

[15] World Health Organisation, 2000. "Water sanitation and health programme. Fluorosis." Available: www.who.int/watersanitationhealth/diseases/fluorosis/en

[16] Satihal, S. S. and Yadawe, M. S., 2014. "Assessment of bacteriological and physicochemical analysis of water." I. J. P. C. B. S., vol. 4, pp. 466-469.

[17] Franciska, M. S., Marcel, D., Ronald, I., and Leo, H., 2005. "Escherichia coli o157: H7 in drinking water from private water supplies in the netherlands." Water Resources, vol. 39, pp. 4485-4493.

[18] Hamida, A., Javed, A., Mohammad, N. A., and Musaddiq, I., 2006. "Bacteriological analysis of drinking water of hand pumps in different schools of district Peshawar (Pakistan)." Pakistan Journal of Food Science, vol. 16, pp. 34-38.

[19] Zahoorullah, T. A., 2003. "Quality of drinking water in rural Peshawar." Pakistan Journal of Med. Res., vol. 42 . 
[20] WHO, 1997. Guidelines for drinking water quality, volume 3: Surveillance and control of community supplies. 2nd ed. Geneva, Switzerland: World Health Organization.

[21] EPA, 2012. "Environmental protection agency basic information about copper in drinking water." Available: http://ater.epa.gov/drinking/contaminants/basicinformation/copper.cfm

[22] Sunday, O. E. and Innocent, C. M., 2012. "Physicochemical and microbiological analysis of water bodies in Uturu, Abia State-Nigeria." Asian Journal of Natural and Applied Sciences, vol. 1, pp. 58-65.

[23] Mustafa, A. I., Ibrahim, A. A., Haruna, Y. I., and Abubakar, S., 2013. "Physicochemical and bacteriological analyses of drinking water from wash boreholes in Maiduguri Metropolis, Borno State, Nigeria." African Journal of Food Science, vol. 7, pp. 9-13.

[24] Satihal, S. S., Magadum, S. R., and Yadawe, M. S., 2015. "Quantitative and qualitative bacterial analysis of underground water of Vijayapur." World Journal of Pharmaceutical Sciences, vol. 3, pp. 1370-1374.

[25] Adenkunle, L. V., Sridhar, M. K. C., Ajayi, A. A., Oluwade, P. A., and Olawuyi, J. F., 2004. "Assessment of the health and socio-economic implication of sachet water in Ibadan, Nigeria." African Journal for Biomedical Research, vol. 7, pp. 5-8.

[26] NSDWQ, 2007. "Nigeria standard for drinking water quality, Nigeria industrial standard." In Approve by Standard Organization of Nigeria Governing Council. ICS 13. 060. pp. 15-19.

[27] Shittu, O. B., O., O. J., and Amusa, T. S., 2008. "Physico-chemical and bacteriological analysis of water used for drinking and swimming purpose." African Journal for Biochemical Research, vol. 11, pp. 285-290.

[28] Roohul-Amin, S., S. A., Zubair, A., and Jabar, Z. K. K., 2012. "Microbial analysis of drinking water and water distribution system in New Urban Peshawar." Current Research Journal of Biological Science, vol. 4, pp. 731-737.

[29] EPA, 2002. "Us environment protection agency, safe drinking water act amendment " Available: http://www.epa.gov/safewater/mcl.Html

[30] Ballester, F. and Sunyer, J., 2000. "Drinking water and gastrointestinal disease, need of better understand and an improvement in public health surveillance." Journal of Epidemiology Community Health, vol. 54, pp. 3-5.

[31] Ho, K. C., Chow, Y. L., and Yau, J. T. S., 2003. "Chemical and biological qualities of east river (dongjiang) water, with particular references in Hong Kong." Chemosphere, IT., vol. 52, pp. 1441-1450. 